\section{KEDUDUKAN KOMISI PENYIARAN INDONESIA \\ DALAM SISTEM KETATANEGARAAN \\ INDONESIA BERDASARKAN UNDANG-UNDANG \\ NOMOR 32 TAHUN 2002 TENTANG \\ PENYIARAN $^{1}$ \\ Oleh: Invy Anggarah Vindy Pangau² \\ Tomm M. R. Kumampung ${ }^{3}$ \\ Syamsia Midu ${ }^{4}$}

\begin{abstract}
ABSTRAK
Tujuan dilakukannya peneltian ini adalah untuk mengetahui bagaimana kedudukan Komisi Penyiaran Indonesia dalam sistem ketatanegaraan Republik Indonesia dan bagaimana pengaturan tentang Komisi Penyiaran Indonesia dan dampak yang diberikan dalam penyiaran di Indonesia. Dengan menggunakan metode penelitian yuridis normative, disimpulkan: 1. KPI adalah sebuah lembaga independen di indonesia yang kedudukannya setingkat dengan lembaga negara lainnya yang berfungsi sebagai regulator penyelenggaraan penyiaran di indonesia. Independen dimaksudkan untuk mempertegas pengelolaan sistem penyiaran yang merupakan ranah publik dikelolah oleh sebuah badan yang bebas dari intervensi modal maupun kepentingan kekuasaan. 2. Pengaturan tentang Komisi Penyiaran Indonesia terdapat dalam Undang-Undang Nomor 32 Tahun 2002 Tentang Penyiaran dan Undang-Undang Dasar Tahun 1945 serta dampak yang diberikan Komisi Penyiaran Indonesia dalam penyiaran di Indonesia yaitu membantu terciptanya jembatan penghubung antara masyarakat dengan pemerintah khususnya dalam dunia penyiaran yaitu salah satunya adalah Komisi Penyiaran Indonesia menampung dan menindaklanjuti keluhan masyarakat sebagai contoh yaitu keluhan mengenai siaran yang layak bagi anak.
\end{abstract}

Kata kunci: Kedudukan, Komisi Penyiaran Indonesia, Sistem Ketatanegaraan, Penyiaran

\footnotetext{
${ }^{1}$ Artikel Skripsi

2 Mahasiswa pada Fakultas Hukum Unsrat, NIM : 16071101201

${ }^{3}$ Fakultas Hukum Unsrat, Magister IImu Hukum

${ }^{4}$ Fakultas Hukum Unsrat, Magister IImu Hukum
}

\section{PENDAHULUAN}

\section{A. Latar Belakang}

Komisi penyiaran Indonesia tidak memiliki kekuasaan penuh untuk mengatur penyiaran Indonesia karena masih harus saling berbagi peran dengan pemerintah. Padahal di dalam undang-undang penyiaran telah disebutkan di dalam Pasal 7 Ayat (2) menjelaskan bahwa Komisi Penyiaran Indonesia sebagai lembaga negara yang bersifat independen mengatur halhal mengenai penyiaran. Jelas penyelenggaraan penyiaran tidak diserahkan kepada pemerintah melainkan kepada Komisi Penyiaran Indonesia sebagai lembaga negara yang independen.

Pembahasan masalah eksistensi komisi negara dalam sistem ketatanegaraan menjadi sangat penting pada saat komisi tersebut akan melaksanakan fungsi, tugas, dan kewenangannya sebagai lembaga pembantu negara, yang disekelilingnya telah berdiri lembaga-lembaga negara yang jelas satu sama lain. Strategis atau tidaknya sebuah komisi akan sangat ditentukan oleh kuat lemahnya kedudukan komisi tersebut dibandingkan lembaga-lembaga negara lain. Oleh karena itu pengkajian diperlukan untuk melihat apakah komisi-komisi ini berkedudukan setara satu sama lain. Dalam lingkup yang mendalam juga penting untuk dikaji apakah komisi-komisi ini berkedudukan sejajar dengan lembaga negara lain ataukah merupakan subordinasi dari lembaga-lembaga tersebut.

\section{B. Perumusan Masalah}

1. Bagaimana kedudukan Komisi Penyiaran Indonesia dalam sistem ketatanegaraan Republik Indonesia?

2. Bagaimana pengaturan tentang Komisi Penyiaran Indonesia dan dampak yang diberikan dalam penyiaran di Indonesia?

\section{Metode Penelitian}

Penelitian merupakan suatu sarana pokok dalam pengembangan ilmu pengetahuan maupun teknologi. Hal ini disebabkan karena penelitian bertujuan untuk mengungkapkan kebenaran secara sistematis, metodologis, dan konsisten. Melalui proses penelitian tersebut diadakan analisis dan konstruksi terhadap data yang telah dikumpulkan. Penelitian yang bersifat deskriptif ini menggunakan pendekatan yuridis normatif yaitu mengacu pada penelitian 
yang dilakukan terhadap bahan hukum primer, sekunder, dan bahan hukum tersier yang berkaitan dengan penelitian ini $^{5}$.

\section{A. Kedudukan Komisi Penyiaran Indonesia Dalam Sistem Ketatanegaraan Republik Indonesia}

Lembaga penyiaran adalah penyelenggara penyiaran, baik lembaga penyiaran publik, lembaga penyiaran swasta, lembaga penyiaran komunitas maupun lembaga penyiaran berlangganan yang dalam melaksanakan tugas, fungsi dan tanggungjawabnya berpedoman pada peraturan perundang-undangan yang berlaku. Komisi Penyiaran Indonesia adalah lembaga Negara yang bersifat independen yang ada di Pusat dan di daerah yang tugas dan wewenangnya diatur dalam Undang-Undang ini sebagai wujud peran serta masyarakat dibidang penyiaran. ${ }^{6}$

Komisi Penyiaran Indonesia (KPI), yang lahir atas amanat Undang-Undang Nomor 2 Tahun 2002 terdiri atas KPI Pusat dan KPI Daerah setingkat Provinsi. Anggota KPI Pusat teerdiri dari 9 orang terpilih yang dipilih oleh Dewan Perwakilan Rakyat dan KPI Daerah yang terdiri dari 7 orang terpilih yang dipilih oleh Dewan Perwakilan Rakyat Daerah. Selain itu, anggaran program kerja KPI Pusat dibiayai oleh APBN dan KPI Daerah oleh APBD. Dalam pelaksanaan tugasnya, KPI dibantu oleh sekretariat tingkat eselon II yang stafnya dari staf Pegawai Negeri Sipil serta staf professional nonPNS. KPI merupakan wujud peran serta masyarakat berfungsi mewadahi aspirasi serta mewakili kepentingan masyarakat akan penyiaran harus mengembangkan program-program kerja hingga akhir kerja dengan selalu memperhatikan tujuan yang diamanatkan Undang-Undang Nomor 2 Tahun 2002 Pasal 3 :

Penyiaran diselenggarakan dengan tujuan untuk memperkukuh integrasi nasional, terbinanya watak dan jati diri bangsa yang beriman dan bertaqwa, mencerdaskan kehidupan bangsa, memajukan kesejahteraan umum, dalam rangka membangun masyarakat yang mandiri, demokratis, adil dan sejahtera serta menumbuhkan industry penyiaran Indonesia." Untuk mencapai tujuan tersebut

\footnotetext{
5 Amirudin dan H. Zainal Asikin, Pengantar Metode Penelitian Hukum, Rajawali Press, Jakarta, 2012, hal 118.

6 Ibid. HIm. 53
}

organisasi KPI dibagi menjadi tiga bidang, yaitu bidang kelembagaan, struktur penyiaran dan pengawasan isi siaran. Bidang kelembagaan menangani persoalan hubungan antara kelembagaan KPI, koordinasi KPID serta pengembangan kelembagaan KPI. Bidang struktur penyiaran bertugas menangani perizinan, industri dan bisnis penyiaran, sedangkan bidang pengawasan isi siaran menangani pemantauan isi siaran, pengaduan masyarakat, advokasi dan literasi media

Hakikat kelembagaan KPI adalah sebagai jembatan diantara lembaga penyiaran dengan masyarakat yang memerlukan informasi dan memerlukan media untuk saling berkomunikasi Didasari bahwa di dalam realisasinya akan memunculkan masalah yang bertumpu pada terbatasnya ruang publik pada satu sisi dan peran media massa pada sisi yang lain.

Peran media massa, idealismenya adalah untuk memberikan informasi dan sebagai media jalinan komunikasi antar sesama warga dan sesama komponen di dalam masyarakat. Dengan jalinan komunikasi dan saling berinformasi secara dinamis masyarakat akan terus berkembang sesuai dengan perkembangan masa.

Namun praktisnya informasi itu merupakan komoditas yang bernilai ekonomis dan karena itu dikembangkan menjadi teknologi informasi pada sisi lain, media massa hendaknya juga tidak menyampaikan sajian yang sifatnya membuka issu baru yang sensitif di masyarakat. KPI merupakan lembaga yang berkewajiban secara konsisten dalam hal ini. Dengan kewajiban demikian masyarakat akan memperoleh informasi yang tidak saja menjadi kebutuhan untuk mengatasi berbagai permasalahan hidup sehari-hari tetapi juga mampu memberi alternatif yang objektif untuk memecahkan berbagai permasalahan di masa yang akan datang. ${ }^{7}$

Kinerja KPI yang sifatnya kontroversial saat ini adalah dalam bidang perizinan. Carut marut pengaturan sistem penyiaran di tanah air yang diharapkan berakhir dengan keluarnya Peraturan Pemerintah sebagai tindak lanjut dari Undang-Undang No. 32 Tahun 2002 Tentang Penyiaran ternyata belum berakhir, bahkan dengan keluarnya 4 Peraturan Pemerintah

\footnotetext{
7 Ibid. HIm. 54
} 
bukan menjernihkan iklim penyiaran tetapi menambah ruwet pengaturan sistem penyiaran.

Di dalam hal sistem penyiaran, UndangUndang memberikan kewenangan kepada KPI untuk menangani perizinan siaran, mengawasi operasionalisasi penyiaran khususnya berkenaan dengan materi siaran. Juga melakukan tindakan yang dipandang perlu sebagai konsekuensi pelanggaran yang aturannya telah ditetapkan oleh $\mathrm{KPI}$, mulai dari teguran tertulis sampai kepada pembekuan izin siaran ketika lembaga penyiaran mempublikasikan sajian yang dinilai bermasalah.2 Kekhususan yang diberikan oleh Undang-Undang ini mengingat kepada tingkat sensitivitas dan strategisnya masalah penyiaran sehingga segala sesuatu yang berhubungan dengan operasionalisasinya, mulai dari seleksi sampai pengawasan diserahkan kepada publik. $\mathrm{KPI}$ adalah representasi publik yang pembentukannya dilakukan berdasar uji kepatutan dan kelayakan oleh lembaga perwakilan (DPR dan DPRD).

Keanggotaannya tidak partisan dan tidak ada kepentingan dengan operasionalisasi penyiaran, semisal punya lembaga penyiaran. Kalau beberapa lembaga yang bergiat di penyiaran berteriak keras atas keluarnya PP itu, bukan berarti mereka berbicara asal beda dan tidak sekedar menurut trend protes terhadap sesuatu yang baru. Substansi yang bertentangan dengan Undang-Undang seharusnya dipahami benar oleh pembuat Peraturan Pemerintah. Tujuannya tidak lain adalah menjaga kewibawaan sebuah peraturan, disamping segera menuntaskan sebuah sistem (dalam hal ini penyiaran) dengan aturan yang justru tidak bertentangan dengan peraturan perundangan yang ada di atasnya.

Dapat dipahami, kondisi sebagaimana yang terjadi saat ini secara praktis adalah munculnya "korban", yaitu sistem penyiaran yang masih carut-marut dan serba tidak menentu. Hal ini berdampak negatif terhadap asas kepastian hukum dan ketataan hukum masyarakat terhadap Undang-Undang. Mekanisme perizinan yang sudah mulai tertata harus mentah kembali menuruti Peraturan Pemerintah yang dinilai tidak sejalan dengan Undang-Undang tersebut. Berdasarkan kenyataan di atas, penyempurnaan secara substansial yang dijadikan sebagai dasar perubahan Undang-undang tentang Penyiaran adalah: mekanisme perizinan, pelakasanaan, pengawaasan dan penindakan dikembalikan secara tegas kepada KPI. Ketentuan ini mesti dicantumkan dengan tanpa menimbulkan poliinterpretasi. Adanya tafsir terhadap istilah Negara di dalam penyempurnaan UndangUndang harus ditegaskan bahwa yang dimaksudkan adalah KPI. Legal reasoning-nya dengan mencermati keberadaan KPI sejak pembentukan sampai kepada mekanisme kinerja yang notabene merupakan representasi publik. Setidaknya yang dimaksudkan Negara bukanlah pemerintah karena asas Hukum Tata Negara di manapun mengajarkan pemerintah adalah eksekutif yang merupakan pelaksana dari Hukum Administrasi.

Komisi Penyiaran Indonesia adalah lembaga negara independen di Indonesia yang kedudukannya setingkat dengan lembaga negara lainnya yang berfungsi sebagai regulator penyelenggaraan penyiaran di Indonesia yang lahir akibat perkembangan masyarakat pasca reformasi.

Hakikat kelembagaan KPI adalah sebagai jembatan diantara lembaga penyiaran dengan masyarakat yang memerlukan informasi dan memerlukan media untuk saling berkomunikasi. Didasari bahwa di dalam realisasinya akan memunculkan masalah yang bertumpu pada terbatasnya ruang publik pada satu sisi dan peran media massa pada sisi yang lain. Peran media massa, idealismenya adalah untuk memberikan informasi dan sebagai media jalinan komunikasi antar sesama warga dan sesama komponen di dalam masyarakat. Dengan jalinan komunikasi dan saling berinformasi secara dinamis masyarakat akan terus berkembang sesuai dengan perkembangan masa. Namun praktisnya informasi itu merupakan komoditas yang bernilai ekonomis dan karena itu dikembangkan menjadi teknologi informasi pada sisi lain, media massa hendaknya juga tidak menyampaikan sajian yang sifatnya membuka issu baru yang sensitif di masyarakat. KPI merupakan lembaga yang berkewajiban secara konsisten dalam hal ini. Dengan kewajiban demikian masyarakat akan memperoleh informasi yang tidak saja menjadi kebutuhan untuk mengatasi berbagai permasalahan hidup 
sehari-hari tetapi juga mampu memberi alternatif yang objektif untuk memecahkan berbagai permasalahan di masa yang akan datang. Kinerja KPI yang sifatnya kontroversial saat ini adalah dalam bidang perizinan. Carut marut pengaturan sistem penyiaran di tanah air yang diharapkan berakhir dengan keluarnya Peraturan Pemerintah sebagai tindak lanjut dari Undang-Undang No. 32 Tahun 2002 Tentang Penyiaran ternyata belum berakhir, bahkan dengan keluarnya 4 Peraturan 30 Pemerintah bukan menjernihkan iklim penyiaran tetapi menambah ruwet pengaturan sistem penyiaran. Di dalam hal sistem penyiaran, Undang-Undang memberikan kewenangan kepada KPI untuk menangani perizinan siaran, mengawasi operasionalisasi penyiaran khususnya berkenaan dengan materi siaran. Juga melakukan tindakan yang dipandang perlu sebagai konsekuensi pelanggaran yang aturannya telah ditetapkan oleh KPI, mulai dari teguran tertulis sampai kepada pembekuan izin siaran ketika lembaga penyiaran mempublikasikan sajian yang dinilai bermasalah. 25 Kekhususan yang diberikan oleh Undang-Undang ini mengingat kepada tingkat sensitivitas dan strategisnya masalah penyiaran sehingga segala sesuatu yang berhubungan dengan operasionalisasinya, mulai dari seleksi sampai pengawasan diserahkan kepada publik. KPI adalah representasi publik yang pembentukannya dilakukan berdasar uji kepatutan dan kelayakan oleh lembaga perwakilan (DPR dan DPRD). Keanggotaannya tidak partisan dan tidak ada kepentingan dengan operasionalisasi penyiaran, semisal punya lembaga penyiaran. Kalau beberapa lembaga yang bergiat di penyiaran berteriak keras atas keluarnya PP itu, bukan berarti mereka bebicara asal beda dan tidak sekedar menurut trend protes terhadap sesuatu yang baru. Substansi yang bertentangan dengan Undang-Undang seharusnya dipahami benar oleh pembuat Peraturan Pemerintah. Tujuannya tidak lain adalah menjaga kewibawaan sebuah peraturan, disamping segera menuntaskan sebuah sistem (dalam hal ini penyiaran) dengan aturan yang justru tidak bertentangan dengan peraturan perundangan yang ada di atasnya.

\section{B. Pengaturan Tentang Komisi Penyiaran Indonesia dan dampak yang diberikan dalam Penyiaran di Indonesia}

Upaya Penguatan KPI merupakan hal yang harus dilakukan oleh negara dalam hal ini pembentuk kebijakan. Adapun hal ini dilakukan untuk memberikan perlindungan kepada masyarakat khususnya terkait dengan kegiatan penyiaran di indonesia. KPI sebagai lembaga negara yang di bentuk oleh undang-undang memerlukan berbagai pembenaan di berbagai sektor, adapun pembenahan ini dilakukan untuk menyelesaikan permasalahanpermasalahan yang ada di dalam KPI. Upaya penguatan KPI akan diulas dalam tiga kategori seperti yang dikatakan oleh Friedman dalam sistem hukum, yaitu melihat dari peraturan, kelembagaan, dan pelaksanaan peraturan perundang-undangan. ${ }^{8}$ Adapun upaya penguatan kelembagaan ini dilakukan melalui perubahan penyiaran. Adapun perubahan UU penyiaran ini merupakan salah satu undangundang yang masuk dalam program Legislasi nasional (Prolegnas) tahun 2015 - 2019 dan menjadi prioritas pembahasan tahun 2015.

Kategori pertama yaitu berkaitan dengan pengaturan. Seperti telah diulas sebelumnya bahwa permasalahan yang ada dalam KPI yaitu belum memadainya peraturan KPI ini menimbulkan permasalahan bagi KPI, dimana KPI belum dapat secara maksimal melaksanakan dalam fungsi, tugas, dan kewenangannya. Pengaturan tentang KPI secara komprehensif tentu saja di perlukan, adapun tujuan dari adanya aturan secara komprehensif ini untuk memberikan perangkat hukum bagi KPI dalam membentuk lembaga, melaksanakan fungsi, tugas, dan wewenangnya, dan produk hukum yang dapat dibentuk dan digunakan bagi KPI. ${ }^{9}$

Perubahan UU penyiaran perlu menyempurnakan pengaturan terkait dengan $\mathrm{KPI}$. Adapun penyempurnaan ini yaitu dengan melakukan memperjelas bentuk kelembagaan $\mathrm{KPI}$, mempertegas fungsi, tugas, dan kewenangan $\mathrm{KPI}$, dan merinci kembali produk hukum yang dapat dibentuk oeleh KPI. Sebagai lembaga negara yang independent, tentu saja

\footnotetext{
8 Net Jimly Asshiddiqie, “Lembaga-Lembaga Negara, Organ Konstitusional Menurut UUD 1945",

http://www.jimly.com, diakses tanggal 21 April 2014. rlbid.
} 
KPI perlu mengkhususkan bidang pekerjaan dari KPI sehingga KPI dapat melaksanakan fungsi, tugas, dan kewenangan KPI dengan maksimal. Pengkhususan ini di maksudkan agar KPI tidak lagi terganggu dengan pekerjaan yang bukan menjadi bagian dari pekerjaan KPI.

Fungsi, tugas, dan kewenangan KPI perlu dilihat kembali, adapun tujuanya yaitu untuk memaksimalkan fungsi, tugas, dan kewenangan KPI agar dapat diimplementasikan oleh KPI. Adapun fungsi KPI yaitu sebagai perwujudan hak masyarakat dalam mengatur isi Siaran di Indonesia. Oleh karena itu dalam menjalankan fungsi dari KPI, maka tugas KPI harus ditambahkan dengan tugas untuk melakukann penelitian dan juga sebagai mediator dalam sengketa penyiaran. Adpun untuk melakukan fungsi dan tugas KPI, maka KPI diberikan kewenangan tambahan yaitu untuk memberikan rekomendasi perpanjangan ijin Penyelengaraan Penyiaran, melakukan audit terhadap pelaksanaan pemeringkatan tingkat kepemirsaan yang diselenggarakan oleh lembaga pemeringkatan, membentuk panel ahli yang bersifat sementara yang terkait dengan permasalahan dan/atau dampak isi siaran, dan melakukan literasi media. ${ }^{10}$

Kategori kedua yaitu tentang kelembagaan. Pasal 1 angka 13 UU penyiaran mengatakan bahwa KPI adalah lembaga negara yang bersifat independen yang ada di pusat dan di daerah yang tugas dan wewenangnya diatur dalam UU Penyiaran sebagai wujud peran serta masyarakat di bidang penyiaran. Berdasarkan Pasal 1 angka 13 tersebut, maka dapat dilihat bahwa dengan tegas UU penyiaran mengatakan bahwa KPI merupakan lembaga negara. Oleh karena itu, maka KPI sebagai lembaga negara, harus memiliki fungsi, tugas, dan kewenangan yang diatur dalam peraturan perundangundangan.

KPI sebagai lembaga negara, tentu saja harus memiliki struktur yang jelas dalam susunan lembaga negara yang ada di indonesia. ${ }^{11}$ Apabila melihat keberadaan lembaga negara yang ada di indonesia, maka dapat dilihat bahwa terdapat 35 (tiga puluh lima) lembaga negara yang harus dibentuk berdasarkan UUD tahun 1945. Pembentukan lembaga negara yang disebutkan dalam UUD

\footnotetext{
10 Ibid.

11 Ibid.
}

tahun 1945 merupakan keharusan atau kewajiban negara untuk membentuk lembagalembaga tersebut. Adapun selain lembaga negara yang di sebutkan dalam UUD tahun 1945, Negara dapat membentuk lembaga atau badan lain yang berkaitan dengan kekuasaan kehakiman. Pembentukan lembaga atau badan lain ini harus dilakukan melalui mekanisme pembentukan undang-undang. Yang dapat dikategorikan sebagai badan-badan lain yang fungsinya berkaitan dengan kekuasaan kehakiman adalah lembaga-lembaga atau badan-badan yang tugasnya berkaitan dengan peradilan dan penegakan hukum, yaitu berhubungan dengan funsi-fungsi:
a) Penyelidikan,
b) Penyidikan,
c) Penuntutan,
d) Pembelaan atau advokasi,
e) Penyelesaian sengketan dan mediasi atau pedamaian,
f) Peradilan, penghakiman dan penghukuman,
g) Pemasyarakatan,
h) Pelaksanaan putusan pengadilan selain pemasyarakatan,
i) Pemulihan nama baik atau rehabilisasi,
j) Pemberian grasi,
k) Pemberian amnesti,
l) Pemberian abolisi,
m) Persaksian, dan
n) Pemberian keterangan berdasarkan keahlian. ${ }^{12}$

Dampak yang diberikan Komisi Penyiaran Indonesia dalam penyiaran di Indonesia yaitu membantu terciptanya jembatan penghubung antara masyarakat dengan pemerintah khususnya dalam dunia penyiaran yaitu salah satunya adalah Komisi Penyiaran Indonesia menampung dan menindaklanjuti keluhan masyarakat sebagai contoh yaitu keluhan mengenai siaran yang layak bagi anak.

Menurut Jimly asshiddiqie, UUD tahun 1945 pasca perubahan menganut pemisahan kekuasaan dengan mengembangkan mekanisme checks and balance yang lebih fungsional. Pemisahan kekuasaan yang ada dalam UUD tahun 1945 tersebut dengan jelas bahwa terdapat pemisahan kekuasaan antara legislatif, eksekutif, dan yudikatif. Adapun kekuasaan atas parlemen ada pada Mejelis

12 Ibid. 
Permusyawaratan Rakyat (MPR), Dewan Perwakilan Rakyat (DPR), dan Dewan Perwakilan Daerah (DPD). Pemegang kekuasaan kehakiman atau yudikatif ada pada Mahkamah Konstitusi dan Mahkamah Agung. Adapun pemegang kekuasaan eksekutif ada pada Presiden dan Wakil Presiden yang juga berperan sebagai kepala pemerintahan. UUD tahun 1945 juga mengamanatkan dibentuknya Badan Pemeriksa Keuangan (BPK) dan Komisi Yudisial (KY). Adpun lembaga tersebut ditunjukan untuk melakukan pengawasan terkait dengan bidang anggaran dan juga pelaksanaan tugas dan kewenangan pemegang kekuasaan yudikatif. Keberadaan BPK dan KY ini tidak dapat dikatakan berdiri sendiri. Keberadaan BPK dan KY ini harus dikaitkan antara tugas dan kewenangan lembaga tersebut dengan tugas dan kewenangan lembaga yang menjadi mitra kerjannya, misalnya saja BPK berkaitan dengan DPR dan $D P D$, sedangkan $K Y$ berkaitan dengan MA.

Bentuk organisasi lembaga negara saat ini mengalami perkembangan yang cukup pesat. Perkembangan ini dikarenakan adanya kewenangan ataupun tugas yang harus dilakukan, akan tetapi lembaga yang sudah ada atau lembaga yang sudah dibentuk berdasarkan UUD tahun 1945 tersebut tidak dapat melaksanakannya. Oleh karena itu, pembentukan badan atau lembaga tersebut dimaksudkan untuk melakukan tugas dan kewenangan yang tidak dapat dilaksanakan tersebut diatas.

Selain lembaga-lembaga negara tersebut, bentuk keorganisasian negara modern dewasa ini juga mengalami perkembangan yang pesat. Ada dua tingkatan, pertama Tentara, organisasi Kepolisian dan Kejaksaan Agung, serta Bank Sentral. Sedangkan pada tingkatan kedua ada Komnas HAM, KPU, Komisi Ombudsman, KPPU, KPK, KKR, dan KPI. Komisi atau lembaga semacam ini selalu diidealkan bersifat independen dan seringkali memiliki fungsi yang sering di campur, yaitu semi-legislatif dan regulatif, semi administratif, dan bahkan semiyudikatif. Dalam kaitannya dengan hal ini terdapat istilah independent self regulatory bodies yang juga berkembang di banyak negara. Di Amerika Serikat, lembaga seperti ini tercatat lebih dari 30-an jumlahnya dan pada umumnya jalur pertanggungjawabannya secara fungsional dikaitkan dengan kongres Amerika Serikat. ${ }^{13}$

Kedudukan KPI sebagai lembaga negara bantu tentu saja menjadi perdebatan tersendiri. Konsep lembaga negara bantu di indonesia belum dapat di terimah sepenuhnya oleh berbagai kalangan. Hal ini dikarenakan masih banyak pendapat para ahli yang mengatakan bahwa konsep lembaga negara bantu tentu saja harus melekat kepada fungsi yang dimiliki oleh legislatif, eksekutif, dan yudikatif. Oleh karena itu, apabila melihat fungsi, tugas, dan kewenangan dari KPI, dapat dilihat bahwa KPI merupakan lembaga yang membantu fungsi, tugas, dan kewenangan dari kementrian komunikasi dan informatika. Apabila melihat dari anggaran yang diperoleh $\mathrm{KPI}$, maka dapat dilihat bahwa KPI mendapatkan anggaran dari APBN yang melekat kepada anggaran Kementrian Komunikasi dan Informatika. ${ }^{14}$ Berdasarkan hal tersebut, maka dengan jelas bahwa saat ini KPI berada di bawah koordinasi Kementerian Komunikasi dan Informatika. Melihat fungsi, tugas, dan kewenangan $\mathrm{KPI}$, maka perlu dijelaskan lebih lanjut bahwa KPI mempunyai kedudukan tersendiri di luar dari ketiga pemisahan kekuasaan yang ada dalam konsep trias politica. KPI sebagai lembaga negara independen seharusnya berada di luar dari kekuasaan tersebut. Akan tetapi apabila melihat fungsi, tugas, dan kewenangan KPI saat ini yang lebih ditekankan kepada pengawasan isi siaran, maka KPI sebagai lembaga negara sudah tepat sebagai mitra dari Kementrian Komunikasi dan Informatika. Hal ini juga bertujuan untuk menciptakan sinergi yang sama antara KPI dengan Kementrian Komunikasi dan Informatika dalam menyelenggarakan kegiatan penyiaran.

\section{PENUTUP}

\section{A. Kesimpulan}

1. KPI adalah sebuah lembaga independen di indonesia yang kedudukannya setingkat dengan lembaga negara lainnya yang berfungsi sebagai regulator penyelenggaraan penyiaran di indonesia. Independen dimaksudkan untuk mempertegas pengelolaan sistem

\footnotetext{
13 Ibid.

14 Ibid.
} 
penyiaran yang merupakan ranah publik dikelolah oleh sebuah badan yang bebas dari intervensi modal maupun kepentingan kekuasaan.

2. Pengaturan tentang Komisi Penyiaran Indonesia terdapat dalam UndangUndang Nomor 32 Tahun 2002 Tentang Penyiaran dan Undang-Undang Dasar Tahun 1945 serta dampak yang diberikan Komisi Penyiaran Indonesia dalam penyiaran di Indonesia yaitu membantu terciptanya jembatan penghubung antara masyarakat dengan pemerintah khususnya dalam dunia penyiaran yaitu salah satunya adalah Komisi Penyiaran Indonesia menampung dan menindaklanjuti keluhan masyarakat sebagai contoh yaitu keluhan mengenai siaran yang layak bagi anak.

B. Saran

1. Perlunya dipertegas bahwa Komisi Penyiaran Indonesia mempunyai kedudukan tersendiri di luar dari ketiga pemisahan kekuasaan yang ada dalam konsep Trias Politica. Komisi Penyiaran Indonesia sebagai lembaga independen seharusnya berada di luar dari kekuasaan tersebut.

2. Perlunya dibuat pengaturan yang mengatur mengenai Komisi Penyiaran Indonesia secara komprehensif agar dalam melakukan tugas, fungsi dan kewenagannya dalam mengatur mengenai penyiaran di Indonesia dapat terlaksanakan secara maksimal.

\section{DAFTAR PUSTAKA}

A. Buku

Amirudin dan Zainal Asikin. Pengantar Metode Penelitian Hukum. Rajawali Pers. Jakarta. 2012

Danrivanto Budhijanto. Hukum Telekomunikasi, Penyiaran, dan Teknologi Informasi. PT. Refika Aditama. Bandung. 2013

Gunawan A.Tauda. Komisi Negara Independen. GENTA Press. Yogjakarta. 2012

Jimly Asshiddiqie. Perkembangan dan Konsolidasi Lembaga Negara
Pasca Reformasi. Sinar Grafika. Jakarta. 2012

--------------------- Pengantar Ilmu Hukum Tata Negara. Rajawali Pers. Jakarta. 2013

Josef M. Monteiro. Lembaga-Lembaga Negara Setelah Amandemen UndangUndang Dasar 1945. Pustaka Yustisia. Yogjakarta. 2014

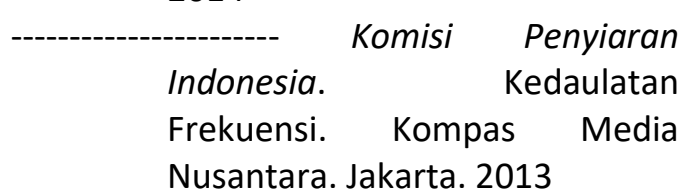

Lukman Hakim. Kedudukan Hukum Komisi Negara di Indonesia. Setara Press. Malang. 2010

Soerjono Soekanto dan Sri Mamudji. Penelitian Hukum Normatif. Rajawali Pers. Jakarta. 2014

Titik Triwulan. Hukum Tata Usaha Negara dan Hukum Acara Peradilan Tata Usaha Negara Indonesia. Kencana Prenadamedia Group. Jakarta. 2011

Zainal Arifin Mochtar. Lembaga Negara Independen. Rajawali Pers. Jakarta. 2016

B. Peraturan Perundang-Undangan

Peraturan KPI Nomor 01/P/KPI/03/2012 Tentang Pedoman Prilaku Penyiaran Peraturan KPI Nomor 02/P/KPI/03/2012 Tentang Standar Program Siaran

Peraturan KPI Nomor 02/P/KPI/04/2011 Tentang Pedoman Rekrutmen Komisi Penyiaran Indonesia

Peraturan KPI Nomor 01/P/KPI/07/2014 Tentang Kelembagaan Komisi Penyiaran Indonesia

Undang-Undang Dasar Tahun 1945

Undang-Undang Nomor 32 Tahun 2002 Tentang Penyiaran

C. Internet

http://m.hukumonline.com/berita/baca/lt5 2a97a1e00d1/pemerintah-dinilaifgagaljalankan-amanat-uu-penyiaran http://www.academia.edu/5625128/PERA NAN_KOMISI_PENYIARAN_IN DONESIA

http:/www.kpi.co.id 
Lex Et Societatis Vol. IX/No. 1/Jan-Mar/2021

http://www.e-

jurnal.com/2013/12/pengertian-komisi-

penyiaranindonesia.html

https://www.lintasparlemen.com/hanura-

anggaran-kpi-

janganlewatkemenkominfo-agar-

independen

http://id.wikipedia.org/wiki/independen 